\title{
Nexus of Electronic Word-Of-Mouth to Social Networking Sites: A Sustainable Chatter of New Digital Social Media
}

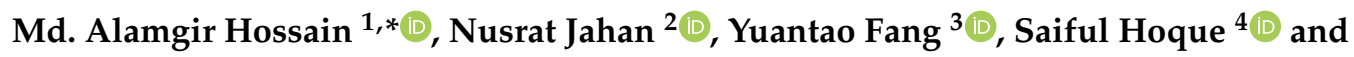 \\ Md. Shakhawat Hossain 5 (D) \\ 1 Department of Management, Hajee Mohammad Danesh Science and Technology University, \\ Dinajpur-5200, Bangladesh \\ 2 Department of Business Administration, Chonbuk National University, Jeonju 54896, Korea; \\ njdisha.bd@gmail.com \\ 3 Department of International Trade, Chonbuk National University, Jeonju 54896, Korea; fytnike@gmail.com \\ 4 School of Media and Communication, Korea University, Seoul 02841, Korea; saiful.hoque1@gmail.com \\ 5 School of Economics and Management, Shanghai Maritime University, Shanghai 1550, China; \\ abir_2384@yahoo.com \\ * Correspondence: shamimru@gmail.com; Tel.: +8801711962321
}

Received: 23 December 2018; Accepted: 26 January 2019; Published: 1 February 2019

\begin{abstract}
The purpose of this study was to examine how electronic word-of-mouth (eWOM) communication of Facebook is influenced by social exchanges, social capital, and service quality dimensions. The online survey was conducted with a pre-tested and self-administered questionnaire, and a structural equation model was used to examine the hypothetical relationships. The results of the structural model provide insights into four key antecedents for the effective use of eWOM communication from a social capital and exchange perspective. In particular, reciprocity, tie strength, trust, and interaction service quality significantly and positively influence eWOM communication, demonstrating that social media users engage in online communication when they have a positive perception toward these psychological dimensions. The comprehensive study offers an extended theoretical perspective on eWOM literature for emerging market context and clearly examines the influencing factors of eWOM that remain to be addressed in this context. Since eWOM is widely used in social media to promote viral marketing through its powerful connection and interpersonal relationship-building capabilities, the results of the study have important implications for the practitioners with respect to sustainable advertising and business strategies.
\end{abstract}

Keywords: electronic word-of-mouth; social capital; social exchange; service quality theory

\section{Introduction}

Currently, it is unthinkable to design any marketing strategy without integrating social networking sites (SNSs). SNSs are well-accepted online platforms for building social relationships between people and enabling them to share their activities, interests, opinions, or information, which creates a fantastic consumer-self marketing communication known as word-of-mouth (WOM). With the rapid growth of internet and information technology, SNSs became the universal electronic WOM (eWOM) channel to share brand-related information through their mobility, ubiquity, and interactivity [1]; they have influence on usage intention, decision-making, and attitude toward services [2,3]. On average, referred customers are $18 \%$ more likely to stay with their existing service provider than others, generating $16 \%$ more profits [4]. Literature indicates that referral communication is more influential than editorial recommendations due to its creditability and persuasiveness [5]. Despite the growing attention 
on SNSs among researchers and marketers, the use of SNSs as eWOM marketing channels is an under-researched phenomenon [2].

Presently, it is not daring to pretend that everyone uses at least one SNS and spends a considerable time using it every day. In this hectic life, people are welcoming alternative solutions to meet their needs and found SNSs as ideal options. People can promptly meet, reach, and discuss with their friends and family with regards to any issues, especially when buying something [1,2]. Electronic WOM comes into contact with a wide range of access and communication capabilities in SNSs. Electronic WOM seized considerable power over traditional marketing strategies to reach potential customers, convince them, and change their purchasing decision for a service or product, becoming an inevitable marketing phenomenon. With regards to richness, time, and cost-effectiveness, eWOM is more convenient than traditional marketing strategies in some aspects; therefore, the current study considers eWOM as an inevitable and sustainable viral marketing strategy.

Among the most popular SNSs, Facebook is used to share individual information, status, opinions, or conversations [6], and it turned SNSs into essential marketing instruments for corporations [7]. Facebook, a global top-ranked SNS, already has more than 2.13 billion monthly active users, and 1.40 billion people log onto Facebook daily, spending 20 minutes per visit [8]. Since its inception in 2004, Facebook users use this SNS to discover what is going on in the world and to stay connected with their friends and family. It is widely accepted by individuals, businesses, and corporations as beneficial in group formation and relationship ties. Numerous researches showed that the reasons for using Facebook are mainly localization and communication with friends and family [9].

While several studies separately explored the motivations of eWOM communication using self-determination theory [3], social exchange theory [10], and social capital theory [11], most of them focused on developed countries (e.g., the United States (US), China, Korea), which limits the validity and applicability of their findings in the context of emerging countries. This study takes into account the context of SNS users in an emerging country, i.e., Bangladesh. In Bangladesh, $80 \%$ of internet users use SNS media, mainly Facebook [12]. A new user of Facebook is added every 12 seconds, which is higher than the birth rate of Bangladesh. Considering the significant future growth trends, consumers have enormous opportunities to engage with eWOM communication. Insights into the use of SNS eWOM by users in Bangladesh can be very valuable in understanding this new digital marketing media. The dominance of Facebook usage among all other SNSs indicates its significant relevance to the current study. This research gap, with a large user base in Bangladesh, provides a unique opportunity to explore the user eWOM communication in this context. In particular, if we want to use these new digital social media in a sustainable way to develop customer relationships and market brands, the issues of eWOM communication and its determinants are remarkably crucial to understand.

The purpose of this study was to examine whether and how eWOM communication is influenced by the integration of social exchange dimensions (reciprocity and reputation), social capital dimensions (tie strength and trust), and service quality dimensions (outcome quality, interaction quality, and environment quality) of Facebook. In addition, this study enriches the literature by investigating the motivations for eWOM in the context of an emerging economy. It is hypothesized that reciprocity, reputation, tie strength, trust, outcome quality, interaction quality, and environment quality positively affect user eWOM communication. In general, if customers have a positive eWOM toward a particular service or product, they may be loyal to that service or product. To test the earlier hypotheses, survey data from 281 Facebook users in Bangladesh were analyzed. The results of this study would have important implications for the design and effective operation of SNS websites that are designed to provide comprehensive social and business services.

The rest of this paper is organized as follows: Section 2 presents the theoretical background and hypotheses. Section 3 is devoted to research design. Empirical results and discussions are presented in Sections 4 and 5, respectively. The final section concludes the paper with valuable implications and future research guidelines. 


\section{Theoretical Background and Hypotheses}

Electronic WOM is an exchange of services or product reviews between people who meet together, talk, or share text on a virtual platform, which has an important impact on consumers' attitudes and purchasing intentions [13]. Due to its credibility and persuasiveness, eWOM communication possesses more influencing power than editorial recommendations and advertisement [5]. Electronic WOM is a completely independent, voluntary, convenient, and safe way for consumers to express their opinion and is a popular way for consumers to disseminate information or learn about other consumers' experiences. Recently, the social media platform Facebook became a cherished and common place for product- or service-related discussions and recommendations [11]. Researchers assume that SNSs changed the customer in terms of customer communication and become an important tool for marketing [14,15]. Furthermore, perceived social support in SNS is considered as an important antecedent of positive emotion toward tourism [15].

Improvements in SNS media transformed the WOM communication process by enabling many users to share product or service information anytime, anywhere [3]. SNSs users are engaged in eWOM communication for a variety of reasons. Cheung and Lee [10] identified different perspectives that explain why consumers spread eWOM communication in online opinion-forming platforms such as Facebook (reputation, reciprocity, sense of belongingness, enjoyment of helping, moral obligations, and knowledge self-efficacy). Wang et al. [3] investigated eWOM through social capital and self-determination theory. Lien et al. [16] and Hossain and Kim [17] discussed hierarchical and multidimensional service quality theory (outcome, interaction, and environment quality) for measuring SNS usage intentions.

This study primarily investigates the relationships between the motivational factors and eWOM in the SNS context. Specifically, the study investigates whether and how the eWOM communication of SNS users is influenced by the factors of social exchange, social capital, and service quality theory. Considering the rigorous analysis of previous literature, this study incorporates reciprocity and reputation factors as a basis for social exchange theory; tie strength and perceived trust are derived from social capital theory; and outcome, interaction, and environment quality are derived from service quality theory. The conceptual research model is shown in Figure 1 along with the hypothesized paths. The additional strengths of the research model and hypotheses are discussed in the paragraphs below.

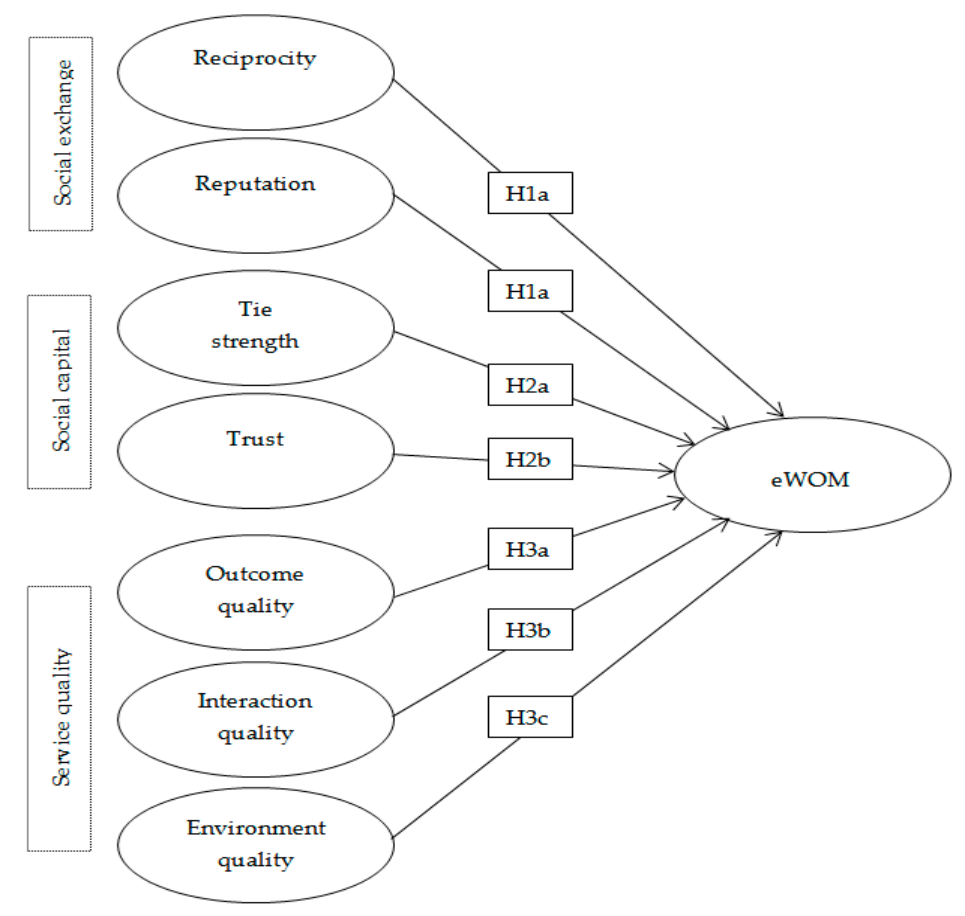

Figure 1. Conceptual research model. 
From the perspective of social exchange theory, individuals seek to generate returns (e.g., reputation, prizes, recognition, or even pay) by maximizing their benefits and minimizing the cost of information sharing [18]. In the interactive communication process, reciprocity and reputation increase social acceptance of an individual's ideas, and build mutual benefits and relationships. People are more willing to share their information on an SNS platform than in face-to-face conversations if the mutual benefit is of interest. In recent years, the theory of social exchange was excessively applied to investigate eWOM in the SNS context [10]. Cheung and Lee [10] identified that reputation, sense of belonging, and altruism had significant positive impacts on consumer participation in eWOM communication (including reputation, reciprocity, sense of belongingness, enjoyment of helping, moral obligations, and knowledge self-efficacy). They also identified that reciprocity has insignificant negative effects on the formation of eWOM. Reputation is often referred to as an important motivation for information sharing. Individuals share information and contribute their knowledge with a view to gaining informal recognition and establishing themselves as experts [19]. Shiau and Luo [20] also assumed that reciprocity has a stronger influence on online group buying satisfaction, and reputation was found to be insignificant. Therefore, this study considers reciprocity and reputation as important motivators for eWOM in the context of an emerging market, and the following hypotheses are proposed:

Hypothesis 1a (H1a). Reciprocity has a positive association with eWOM.

Hypothesis 1b (H1b). Reputation has a positive association with eWOM.

In addition, the relationship between social capital and SNS usage was examined by various researchers who suggested that users engage in eWOM to increase social capital. Social capital refers to individuals in social network who wish to contribute reciprocal functions and obligations to accumulate "the collectively owned capital" [21]. It includes relational, structural, and cognitive attributes. Ties are a key factor in the structural attribute, describing how users receive and share information in order to gain mutual benefits. Trust is an important facet of relational attributes that stimulate network growth. In the study by Wang et al. [3], they analyzed dimensions of social capital (e.g., tie strength, trust, and shared language) to measure eWOM, and concluded that tie strength has a significant influence on eWOM. Social capital positively influences opinion-giving and -seeking behaviors, which in turn affects eWOM communication [11]. Social outcome expectations have a strong and positive influence on the behavioral intentions of eWOM [22]. Therefore, this study considers tie strength and trust in SNS as the key social capital factors to investigate eWOM behavior, and the following hypotheses are proposed:

Hypothesis 2a (H2a). Tie strength has a positive association with eWOM.

Hypothesis $\mathbf{2 b} \mathbf{( H 2 b )}$. Trust has a positive association with eWOM.

Service quality was widely discussed in the SNSs context for measuring one's intention to use a product/service continually $[16,17,23]$. Lien et al. [16] examined the intentions of WeChat users from the perspective of multidimensional and hierarchical service quality and pointed out that the outcome and environment quality of WeChat significantly affect user satisfaction. Zhao et al. [23] reported that interaction, environment, and outcome quality have significant influence on cumulative satisfaction. The present study employs this multidimensional service quality theory experimentally to measure eWOM communication. Gounaris et al. [24] showed how WOM communications of electronic (e)-consumers are being affected by e-service quality, and pointed out that e-satisfaction, intentions, and WOM communication are positively influenced. If customers are loyal to the e-service providers, they are willing to say something positive about these service providers [25]. Another study from the healthcare industry argued that service quality directly affects consumer WOM communication [26]. 
Therefore, it is also hypothesized that the multidimensional service quality dimensions of outcome, interaction, and environment quality are positively related to eWOM.

Hypothesis 3a (H3a). Outcome service quality has a positive association with eWOM.

Hypothesis $\mathbf{3 b} \mathbf{( H 3 b )}$. Interaction service quality has a positive association with eWOM.

Hypothesis 3c (H3c). Environment service quality has a positive association with eWOM.

\section{Research Design}

The study used an online/web-based survey to communicate with the potential respondents via Facebook. As an instrument measure, a structured questionnaire was built using Google Docs and was sent to respondents on a random sampling basis. The designed study questionnaire included measures for the constructs and the demographic background of the respondents. Brief messages were sent to explain the purpose of the study and to ask them to take part in survey if they found interest. In addition, participants were assured that their responses would be kept strictly private and only used for the study purpose. Initially, the study pre-tested the questionnaire with several university professors and researchers, and removed or reworded some ambiguous questions where necessary. Furthermore, a pilot study with 24 samples was performed, and the results showed a sufficient reliability of the measurement constructs.

The final survey was conducted during the month starting 21 August 2017 in Bangladesh. A total of 347 completed samples were received. The responses were checked for validity, total time spent responding, and completeness. After removing invalid responses and achieving multivariate normality, we eliminated 66 samples from our study. Finally, we were left with 281 valid samples to test the study purpose. The data collection method and sample size were sufficiently harmonized with earlier studies by Wang el al. [3], Kucukemiroglu and Kara [11], Shiau and Luo [20], and many others. Wang et al. [3] conducted an online-based survey of 238 samples to assess what drives eWOM in the context of SNS. Kucukemiroglu and Kara [11] considered a sample size of only 149 to evaluate eWOM. Similarly, Shiau and Luo [20] examined factors affecting online group buying intention and satisfaction through an online survey of 215 samples. Therefore, this study asserted that the data collection method was valid and the final sample size was sufficient to examine the proposed model. In addition, the samples came from across the country (e.g., including various urban, rural, racial, religious demographics) through random sampling, showing that the samples were representative of the study population.

The empirical analysis of this study used methodologies adapted from published guidelines for construct development and validation. The study used a two-step approach to ensure the results were more meaningful than using the one-step approach suggested by Anderson and Gerbing [27]. In the first step, we performed confirmatory factor analysis using AMOS-24 for eight multi-item measurements to test a measurement theory based on the overall model fit, internal consistency, construct reliability, and validity. Thereafter, the structural equation modeling approach was used to measure the hypothesized relationship among constructs.

\subsection{Instrument Design}

As a survey instrument, we used established measures from previous researches where possible. Minor modifications were made to the measurement scales to ensure suitability for the context. There were eight constructs, comprising reciprocity, reputation, tie strength, trust, outcome quality, interaction quality, environment quality, and eWOM, used to examine the conceptual hypotheses. This study adopted the measures of eWOM, reciprocity, and reputation from Cheung and Lee [10], Kucukemiroglu and Kara [11], Shiau and Luo [20]. Tie strength and trust were modified from Cheung and Lee [10] and Wang et al. [3]. The measurement items of outcome, interaction, and environment 
quality were adopted and modified from Hossain and Kim [17] and Lien et al [16]. All constructs were measured using multi-item perceptual scales and carried out using a five-point Likert scale, ranging from strongly disagree (1) to strongly agree (5). All 24 measurement items and their corresponding constructs are shown in Table 1, comprising three items for each construct. Table 1 also displays item-wise descriptive statistics.

Table 1. Summary of measurement items and descriptive statistics.

\begin{tabular}{|c|c|c|c|c|c|}
\hline \multicolumn{3}{|c|}{ Constructs and Measurement Items } & \multirow{2}{*}{$\begin{array}{c}\begin{array}{c}\text { Squared Multiple } \\
\text { Correlation }\end{array} \\
0.405\end{array}$} & \multirow{2}{*}{$\begin{array}{c}\text { Mean } \\
3.60\end{array}$} & \multirow{2}{*}{$\begin{array}{c}\begin{array}{r}\text { Standard } \\
\text { Deviation }\end{array} \\
1.01\end{array}$} \\
\hline \multirow{3}{*}{$\begin{array}{l}\text { Reciprocity } \\
{[10,20]}\end{array}$} & $\mathrm{RC} 1$ & $\begin{array}{l}\text { When I share my information on } \\
\text { Facebook, I believe that I will receive } \\
\text { other information from other users. }\end{array}$ & & & \\
\hline & $\mathrm{RC} 2$ & $\begin{array}{l}\text { When I share my information on } \\
\text { Facebook, I expect somebody to } \\
\text { respond when I am in need. }\end{array}$ & 0.586 & 3.70 & 0.89 \\
\hline & $\mathrm{RC} 3$ & $\begin{array}{l}\text { I think that participating in sharing } \\
\text { information on Facebook can improve } \\
\text { reciprocal benefits. }\end{array}$ & 0.598 & 3.79 & 0.78 \\
\hline \multirow{3}{*}{$\begin{array}{l}\text { Reputation } \\
\text { [10] }\end{array}$} & RP1 & $\begin{array}{l}\text { I feel that my participation on } \\
\text { Facebook improves my status. }\end{array}$ & 0.617 & 3.91 & 0.85 \\
\hline & $\mathrm{RP} 2$ & $\begin{array}{l}\text { I participate in discussions on } \\
\text { Facebook to improve my reputation. }\end{array}$ & 0.674 & 4.10 & 0.81 \\
\hline & $\mathrm{RP3}$ & $\begin{array}{l}\text { I earn more respect from others by } \\
\text { joining in discussions on Facebook. }\end{array}$ & 0.593 & 3.81 & 0.96 \\
\hline \multirow{3}{*}{ Tie strength [3] } & TS1 & $\begin{array}{l}\text { I communicate very frequently with } \\
\text { the contacts on my friend list on my } \\
\text { social network. }\end{array}$ & 0.634 & 4.19 & 0.82 \\
\hline & TS2 & $\begin{array}{l}\text { Overall, I feel very close to the } \\
\text { contacts on my friend list on } \\
\text { social networks. }\end{array}$ & 0.432 & 3.78 & 0.98 \\
\hline & TS3 & $\begin{array}{l}\text { To a very great extent, I typically } \\
\text { interact with each person }\end{array}$ & 0.662 & 3.91 & 0.84 \\
\hline \multirow{3}{*}{ Trust $[3,11]$} & TR1 & $\begin{array}{l}\text { I trust most contacts on my friend list } \\
\text { on social networks. }\end{array}$ & 0.771 & 3.84 & 0.78 \\
\hline & TR2 & $\begin{array}{l}\text { My contacts on my friend list on } \\
\text { Facebook offer honest opinions. } \\
\text { I feel confident about having }\end{array}$ & 0.768 & 3.77 & 0.84 \\
\hline & TR3 & $\begin{array}{l}\text { discussions with the contacts on my } \\
\text { friend list on Facebook. }\end{array}$ & 0.600 & 3.81 & 0.86 \\
\hline \multirow{3}{*}{$\begin{array}{c}\text { Outcome } \\
\text { quality }[16,17]\end{array}$} & OQ1 & $\begin{array}{l}\text { I can save considerable time and } \\
\text { effort via Facebook communication. }\end{array}$ & 0.661 & 4.11 & 0.85 \\
\hline & OQ2 & $\begin{array}{c}\text { Facebook delivers information } \\
\text { very quickly. }\end{array}$ & 0.616 & 4.08 & 0.87 \\
\hline & OQ3 & $\begin{array}{l}\text { Facebook provides } \\
\text { important information. }\end{array}$ & 0.353 & 4.06 & 0.89 \\
\hline \multirow{3}{*}{$\begin{array}{l}\text { Interaction } \\
\text { quality }[16,17]\end{array}$} & IQ1 & $\begin{array}{l}\text { Facebook authorities are } \\
\text { very friendly. }\end{array}$ & 0.585 & 3.66 & 0.85 \\
\hline & IQ2 & $\begin{array}{l}\text { Facebook authorities are willing to } \\
\text { solve my problem. }\end{array}$ & 0.722 & 3.42 & 0.96 \\
\hline & IQ3 & $\begin{array}{l}\text { Facebook is able to answer to my } \\
\text { questions thoroughly. }\end{array}$ & 0.564 & 3.14 & 0.97 \\
\hline \multirow{3}{*}{$\begin{array}{l}\text { Environment } \\
\text { quality }[16,17]\end{array}$} & EQ1 & Facebook's display is easy to use. & 0.378 & 4.08 & 0.97 \\
\hline & $\mathrm{EQ} 2$ & $\begin{array}{l}\text { Facebook provides useful "emotional } \\
\text { expression" icons. }\end{array}$ & 0.657 & 4.16 & 0.86 \\
\hline & EQ3 & $\begin{array}{l}\text { Facebook provides useful supporting } \\
\text { tools (e.g., photos, message sharing). }\end{array}$ & 0.522 & 3.93 & 0.95 \\
\hline \multirow{3}{*}{$\begin{array}{c}\text { Electronic } \\
\text { word-of-mouth } \\
{[10,11]}\end{array}$} & eWOM1 & $\begin{array}{l}\text { I would like to share my experiences } \\
\text { with others on Facebook more } \\
\text { frequently in the future. }\end{array}$ & 0.602 & 3.75 & 0.81 \\
\hline & eWOM2 & $\begin{array}{l}\text { I tend to forward my friends positive } \\
\text { reviews on products/services. }\end{array}$ & 0.604 & 3.71 & 0.84 \\
\hline & eWOM3 & $\begin{array}{l}\text { I like to share with others my favorite } \\
\text { products/services. }\end{array}$ & 0.602 & 3.63 & 0.88 \\
\hline
\end{tabular}

Note: Items were measured using a five-point Likert scale, ranging from strongly disagree (1) to strongly agree (5). 


\subsection{Data}

Among all respondents, $31.74 \%$ of them were between 26 and 30 years old and $30.96 \%$ were between 31 and 35 years old. Recent demographic data reaffirmed that young adults between the ages 26 and 35 are dominant Facebook users (62.7\%). The gender was approximately evenly split (54.09\% female and $45.90 \%$ male). Overall, $63 \%$ of them spent 30 minutes to one hour a day on Facebook and more than $86 \%$ of respondents joined Facebook three or more years ago. The demographic characteristics of the samples show that this study comprised experience-based samples for its empirical analysis, and that it was inevitable to attain actual results. Detailed demographic characteristics of the respondents are shown in Table 2.

Table 2. Demographic characteristics.

\begin{tabular}{cccc}
\hline \multicolumn{2}{c}{ Characteristics } & Frequency & \% \\
\hline Age & $19-25$ & 48 & 17.08 \\
& $26-30$ & 92 & 31.74 \\
\multirow{3}{*}{ Gender } & $31-35$ & 87 & 30.96 \\
& Over 36 & 54 & 19.21 \\
Average usage per day & Female & 152 & 54.09 \\
& Male & 129 & 45.90 \\
\multirow{2}{*}{ Usage experience } & Below 30 minutes & 34 & 12.09 \\
& 30 minutes to 1 hour & 179 & 63.70 \\
& More than 1 hour & 68 & 24.19 \\
& 1-2 years & 7 & 0.02 \\
& 2-3 years & 31 & 11.03 \\
& More than 3 years & 243 & 86.47 \\
\hline
\end{tabular}

Source: Survey data.

\section{Data Analysis and Results}

Data analyses were carried out in two phases. The measurement model was first tested to assess the data reliability and validity of the constructs. An examination of the measurement model included (1) internal consistency, (2) individual item-wise reliability, (3) discriminant validity, (4) multicollinearity, (5) overall model fit, and (6) common method variance (CMV). After satisfying the validity and reliability criteria of the measurement model, we tested the structural model. In the structural model examination, a partial least-squares analysis was performed to assess hypothetical relationships between independent and dependent variables. The results of the structural model provided the path coefficient for the endogenous latent variables and the $R^{2}$ value.

\subsection{Measurement Model}

Internal consistency was examined using composite reliability (CR), showing that all CR values exceeded the threshold of 0.70 , demonstrating excellent reliability [28]. The study also tested internal consistency reliability by examining construct-wise Chronbach's alpha, with values ranging from 0.75 to 0.86 , representing good internal consistency. The measurement model's reliability and validity statistics are shown in Table 3. The convergent validity was tested using the three criteria of average variance extracted (AVE), factor loadings, and squared multiple correlations (SMCs), as suggested by Hair et al. [28] and Fornell and Larcker [29]. The AVE value for each construct exceeded its cut-off value 0.50 [29], the average factor loadings exceeded 0.70 (see Table 3), and the values of SMC exceeded 0.50 (see Table 1), representing good convergent validity [28]. 
Table 3. Measurement model's reliability and validity.

\begin{tabular}{|c|c|c|c|c|}
\hline $\begin{array}{l}\text { Measurement } \\
\text { Items }\end{array}$ & $\begin{array}{l}\text { Standardized } \\
\text { Estimates }\end{array}$ & $\begin{array}{l}\text { Average Variance } \\
\text { Extracted (AVE) }\end{array}$ & $\begin{array}{c}\text { Composite } \\
\text { Reliability (CR) }\end{array}$ & Cronbach's Alpha \\
\hline Reciprocity & & 0.53 & 0.77 & 0.77 \\
\hline RC1 & 0.637 & & & \\
\hline $\mathrm{RC} 2$ & $0.766 *$ & & & \\
\hline $\mathrm{RC} 3$ & $0.878 *$ & & & \\
\hline Reputation & & 0.63 & 0.83 & 0.83 \\
\hline $\mathrm{RP} 1$ & $0.785^{*}$ & & & \\
\hline RP2 & 0.821 * & & & \\
\hline RP3 & 0.770 & & & \\
\hline Tie strength & & 0.58 & 0.80 & 0.80 \\
\hline TS1 & 0.796 & & & \\
\hline TS2 & 0.657 * & & & \\
\hline TS3 & $0.814^{*}$ & & & \\
\hline Trust & & 0.71 & 0.89 & 0.86 \\
\hline TR1 & 0.878 & & & \\
\hline TR2 & $0.876^{*}$ & & & \\
\hline TR3 & 0.775 * & & & \\
\hline Outcome quality & & 0.54 & 0.78 & 0.76 \\
\hline OQ1 & 0.813 * & & & \\
\hline OQ2 & 0.785 * & & & \\
\hline OQ3 & 0.600 & & & \\
\hline Interaction quality & & 0.62 & 0.83 & 0.82 \\
\hline IQ1 & $0.765 *$ & & & \\
\hline IQ2 & 0.850 * & & & \\
\hline IQ3 & 0.751 & & & \\
\hline $\begin{array}{l}\text { Environment } \\
\text { quality }\end{array}$ & & 0.52 & 0.76 & 0.75 \\
\hline EQ1 & 0.615 * & & & \\
\hline EQ2 & 0.811 * & & & \\
\hline EQ3 & 0.723 & & & \\
\hline $\begin{array}{c}\text { Electronic } \\
\text { word-of-mouth }\end{array}$ & & 0.59 & 0.81 & 0.80 \\
\hline eWOM1 & 0.776 & & & \\
\hline eWOM2 & 0.777 * & & & \\
\hline eWOM3 & $0.742 *$ & & & \\
\hline
\end{tabular}

To examine discriminant validity, the square roots of the AVE were compared with the correlations between constructs. The lowest square roots of the AVE value of environment quality (0.72) were higher than the highest correlation value, confirming the discriminant validity of the constructs. In addition, the multicollinearity among the independent variables was assessed using the variance inflation factor (VIF), which ranged from 1.33 to 3.17 (within the threshold of 10), representing no multicollinearity issues [28]. Correlation and discriminant validity statistics are shown in Table 4. In addition, Table 5 shows the results of the absolute model fit indices $\left(\mathrm{X}^{2} /\right.$ degrees of freedom $(\mathrm{df})=1.589$; root-mean-square error of approximation $($ RMSEA $)=0.04)$ and the incremental model fit indices (goodness-of-fit index $(\mathrm{GFI})=0.90$, adjusted GFI $(\mathrm{AGFI})=0.88$, confirmatory fit index $(\mathrm{CFI})=0.96$, normed fit index $(\mathrm{NFI})=0.91$, incremental fit index $(\mathrm{IFI})=0.97$, and Tucker-Lewis index $(\mathrm{TLI})=0.96$ ), which exhibit a good model fit based on the criteria of Hair et al. [28]. 
Table 4. Correlation and discriminant validity. VIF-variance inflation factor.

\begin{tabular}{|c|c|c|c|c|c|c|c|c|c|c|c|c|}
\hline Constructs & Mean & $\begin{array}{l}\text { Standard } \\
\text { Deviation }\end{array}$ & $\mathrm{RC}$ & $\mathbf{R P}$ & TS & TR & OQ & IQ & EQ & eWOM & Tolerance & VIF \\
\hline $\mathrm{RC}$ & 3.699 & 0.746 & 0.73 & & & & & & & & 0.342 & 2.92 \\
\hline $\mathrm{RP}$ & 3.944 & 0.760 & 0.67 & 0.80 & & & & & & & 0.315 & 3.17 \\
\hline TS & 3.963 & 0.748 & 0.70 & 0.65 & 0.76 & & & & & & 0.371 & 2.69 \\
\hline TR & 3.811 & 0.744 & 0.72 & 0.75 & 0.69 & 0.84 & & & & & 0.353 & 2.83 \\
\hline OQ & 4.086 & 0.722 & 0.49 & 0.56 & 0.48 & 0.54 & 0.73 & & & & 0.693 & 1.44 \\
\hline IQ & 3.415 & 0.805 & 0.50 & 0.51 & 0.47 & 0.46 & 0.44 & 0.78 & & & 0.751 & 1.33 \\
\hline EQ & 4.058 & 0.760 & 0.71 & 0.63 & 0.65 & 0.70 & 0.54 & 0.38 & 0.72 & & 0.573 & 1.74 \\
\hline eWOM & 3.698 & 0.720 & 0.60 & 0.71 & 0.68 & 0.61 & 0.53 & 0.60 & 0.64 & 0.77 & & \\
\hline
\end{tabular}

Note: Bold diagonal values are the square root of average variance extracted (AVE).

Table 5. The results of model fit indices.

\begin{tabular}{ccc}
\hline Model Fit Indices & Suggested Value & Obtained Value \\
\hline The ratio of chi-square to degrees of freedom $\left(\mathrm{X}^{2} / \mathrm{df}\right)$ & $<3$ & 1.589 \\
Goodness-of-fit index (GFI) & $>0.90$ & 0.90 \\
Average GFI & $\geq 0.80$ & 0.88 \\
Comparative fit index (CFI) & $\geq 0.90$ & 0.96 \\
Normalized fit index (NFI) & $\geq 0.90$ & 0.91 \\
Incremental fit index (IFI) & $\geq 0.90$ & 0.97 \\
Tucker-Lewis index (TLI) & $\geq 0.90$ & 0.96 \\
Root-mean-square error of approximation (RMSEA) & $\leq 0.05$ & 0.04 \\
\hline
\end{tabular}

Source: AMOS output.

Finlay, CMV was confirmed by conducting Harman's single-factor test suggested by Podsakoff et al. [30]. If all factors fall under a single construct or if only one factor explain more than $50 \%$ of the variances, a CMV issue arises. Here, the first factor accounted for $43 \%$, and several factors with eigenvalues had values more than 1 , suggesting no CMV issue. In summary, the measurement model demonstrates a sufficient model fit, as well as good reliability and validity of the constructs.

\subsection{Structural Model}

In the second step, a structural equation model was conducted to evaluate the hypothetical relationships among constructs. Figure 2 presents the hypothetical relationships among study constructs and eWOM. The results of the analysis showed that reciprocity, tie strength, trust, and interaction quality explained $59 \%$ of the variance in eWOM communication. The $R^{2}$ value represents how the proposed model contributed to the dependent variable eWOM.

Table 6 shows the results of the research model in detail with standardized estimates $(\beta)$, standard errors, $t$-values, significant values, and decisions on hypotheses. Hypotheses H1a and $\mathrm{H} 1 \mathrm{~b}$ examined the positive influence of social exchange dimensions of reciprocity and reputation on eWOM communication. Reciprocity in Facebook was positively and significantly associated with $\operatorname{eWOM}(\beta=0.196, p<0.05)$; thus, H1a was accepted. However, the influence of reputation on eWOM was marginally positive ( $\beta=0.009, p=0.89)$; thus, H1b was rejected. The study, therefore, portrays that these social exchange dimensions remain relevant and important in SNS research. 


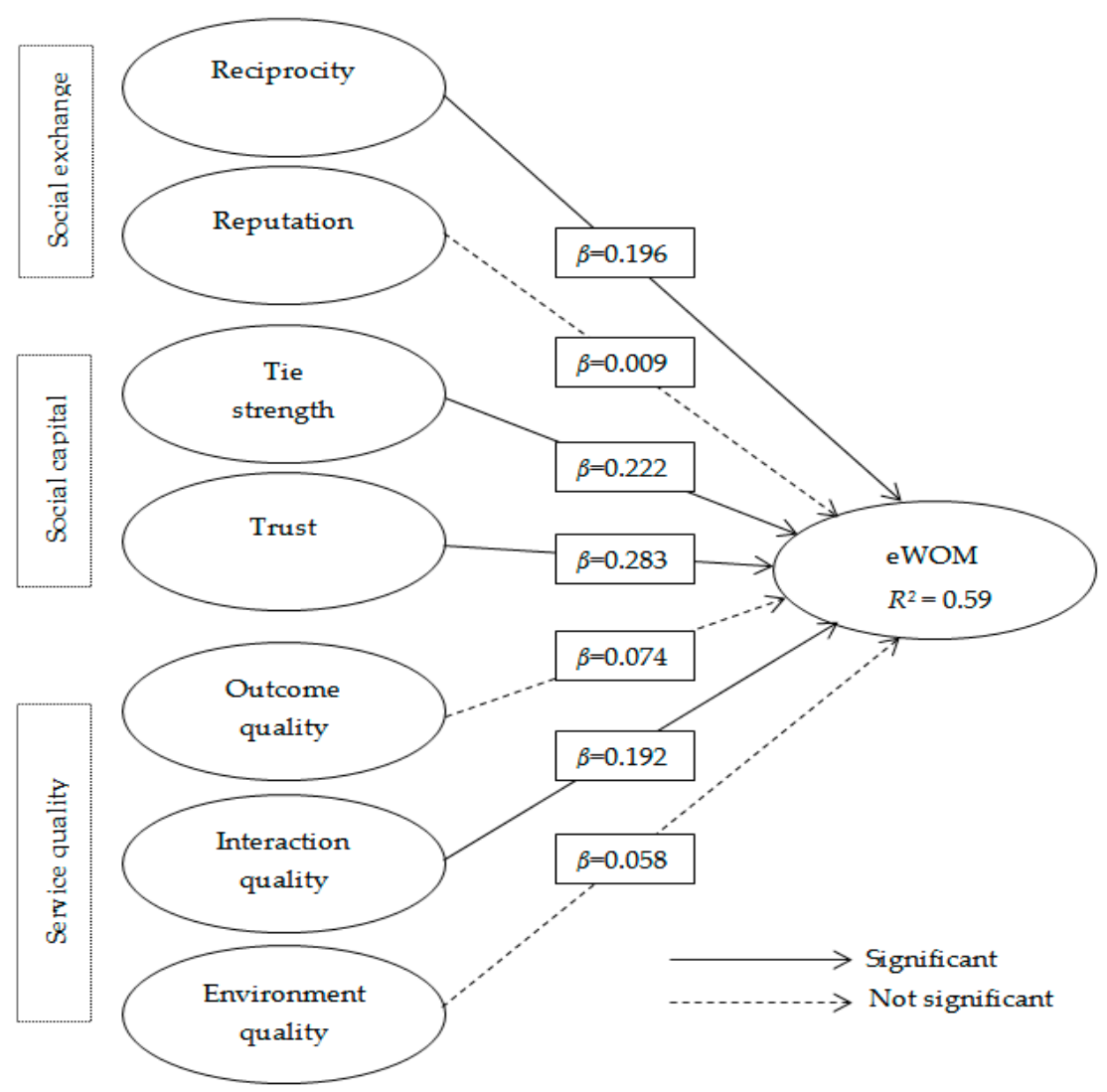

Figure 2. Structural model.

Table 6. Summary of hypothesis results.

\begin{tabular}{|c|c|c|c|c|c|c|c|c|}
\hline \multicolumn{4}{|c|}{ Hypothesized Paths } & \multirow{2}{*}{$\begin{array}{c}\text { Estimate } \\
(\boldsymbol{\beta})\end{array}$} & \multirow{2}{*}{$\begin{array}{c}\begin{array}{c}\text { Standard } \\
\text { Error }\end{array} \\
0.063\end{array}$} & \multirow{2}{*}{$\begin{array}{c}\boldsymbol{t} \text {-Value } \\
2.990\end{array}$} & \multirow{2}{*}{$\begin{array}{c}p \text {-Value } \\
* *\end{array}$} & \multirow{2}{*}{$\begin{array}{l}\text { Decision } \\
\text { Accept }\end{array}$} \\
\hline $\mathrm{H} 1 \mathrm{a}$ & Reciprocity & $\rightarrow$ & eWOM & & & & & \\
\hline$H 1 b$ & Reputation & $\rightarrow$ & eWOM & 0.009 & 0.065 & 0.131 & $>0.05$ & Reject \\
\hline $\mathrm{H} 2 a$ & Tie strength & $\rightarrow$ & eWOM & 0.222 & 0.061 & 3.530 & $* * *$ & Accept \\
\hline$H 2 b$ & Trust & $\rightarrow$ & eWOM & 0.238 & 0.063 & 3.684 & $* * *$ & Accept \\
\hline$H 3 a$ & Outcome quality & $\rightarrow$ & eWOM & 0.074 & 0.046 & 1.607 & $>0.05$ & Reject \\
\hline$H 3 b$ & Interaction quality & $\rightarrow$ & eWOM & 0.192 & 0.040 & 4.329 & $* * *$ & Accept \\
\hline$H 3 c$ & $\begin{array}{l}\text { Environment } \\
\text { quality }\end{array}$ & $\rightarrow$ & eWOM & 0.058 & 0.048 & 1.137 & $>0.05$ & Reject \\
\hline \multicolumn{9}{|c|}{$R^{2}$ of $\mathrm{eWOM}=0.59$} \\
\hline
\end{tabular}

Note: ${ }^{* * *} p<0.001 ;{ }^{* *} p<0.05$.

Hypotheses $\mathrm{H} 2 \mathrm{a}$ and $\mathrm{H} 2 \mathrm{~b}$ that tested the influence of social capital's perspective on eWOM communication were accepted. The tie strength and trust on Facebook were positively and significantly related with eWOM $(\beta=0.222, p<0.001$, and $\beta=0.238, p<0.001$, respectively), supporting H2a and $\mathrm{H} 2 \mathrm{~b}$. Therefore, it was demonstrated that the perspective of social capital is the best predictor of SNS eWOM communication.

Hypotheses $\mathrm{H} 3 \mathrm{a}, \mathrm{H} 3 \mathrm{~b}$, and $\mathrm{H} 3 \mathrm{c}$ identified the effect of multidimensional service quality on eWOM. Among them, only $\mathrm{H} 3 \mathrm{~b}$ was accepted because the interaction quality positively and significantly affected the eWOM ( $\beta=0.192, p<0.001)$, and the remaining two hypotheses H3a and H3c were rejected because they had a negligible effect on $\operatorname{eWOM}(\beta=0.074, p=0.10$, and $\beta=0.05, p=0.25$, respectively).

\section{Discussion}

The results of the present study empirically portrayed how social exchanges, social capital, and multidimensional service quality stimulated the motivation of SNS users to participate in eWOM 
communication. Specifically, four antecedents (reciprocity, tie strength, trust, and interaction quality) have significant impact on eWOM communication of Facebook users.

The findings of this study proved that the proposed model provides satisfactory explanatory power for eWOM in the SNS context. The results show that reciprocity has a positive and significant impact on eWOM communication, whereas, contrary to expectations, no significant impact of reputation on eWOM was identified. These findings are in contradiction to the study by Cheung and Lee [10], which stated that consumers engaging in eWOM communication do so to strengthen their reputation without worrying about reciprocity. In terms of social exchange perspectives, Bangladeshi SNSs users might be too reciprocal to build and maintain mutual beneficial relationships with social networking partners, while personal recognition and reputation are given less priority. Therefore, eWOM motivations between developed and emerging countries are not similar from the perspective of social exchange theory.

Trust is one of the important social capital dimensions with the greatest impact on user eWOM communication. This result is in line with earlier eWOM marketing literature by Kucukemiroglu and Kara [11], who noted that trust is the important determinant in opinion-giving and opinion-seeking behaviors, which in turn affects eWOM. Therefore, users tend to show a higher level of positive intention to eWOM when users trust their contacts on Facebook. Those who trust close friends on Facebook are more likely to participate in eWOM communication, which results in active product recommendations to their friends. Moreover, the social capital dimension of tie strength positively and significantly influences eWOM communication, which is consistent with Wang et al. [3]. Consequently, SNSs users tend to give and seek advice from people with close relationships (e.g., friends and family members) and are more willing to share information about services or products with their close friends than acquaintances.

Of the newly incorporated, multidimensional service quality dimensions, only the interaction service quality has a significant positive impact on eWOM, which corroborates the results of Hossain and Kim [17]. Although outcome quality and environment quality did not seem significant, these two dimensions still have a positive impact on the intent of eWOM. In the SNS context, Lien et al. [16] applied these service quality dimensions and reported that outcome and environment quality have a significant impact on intended use. As SNS is becoming more popular worldwide, service quality dimensions could, therefore, play an important role in the design of eWOM communication, which in turn offers extensive opportunities to marketers in the form of viral marketing.

The fact that SNS users typically add other users with whom they are already somewhat connected in real life makes relationships as livable as close friends and family members. As such, SNS users generate a higher level of bridging and bonding social capital, build mutually beneficial relationships, and engage in superior eWOM communication. In addition, SNS users also add other users whom they idolize and deem famous in their lives or in their society, thereby building and sharing relationships. As such, due to the public nature of the relationship with SNSs, users derive a higher level of sharing intention, essentially engaging in the viral marketing phenomenon. Therefore, this study asserts that eWOM in SNSs has an incredible impact on user behavior, particularly in purchasing decision, through its superior communication power and greater accessibility in the virtual world.

\section{Conclusions}

This study aimed to draw the important factors from different theories that are empirically and logically related to eWOM communication. The results of the structural model provide insights into four key precursors for the effective use of eWOM communication from the perspective of social capital and exchange. Reciprocity, tie strength, trust, and interaction service quality have a significant and positive impact on eWOM communication, revealing that social media users engage in online communication if they have a positive perception toward these psychological dimensions.

The results of this study shed light on some important aspects related to the critical determination of eWOM communication from SNSs users, which remain to be addressed. Firstly, this study was 
the first attempt to integrate the theories of social exchange, social capital, and service quality, and to examine the direct effect of each dimension of these theories on the intention to partake in eWOM communication. The result implies that psychological dimensions in the digital content industry are more important than the technological dimensions. In particular, this study revealed that social capital factors such as tie strength and trust have a significant influence on eWOM communication. This study also provided empirical evidence that reciprocity and interaction service quality are crucial motivators for user engagement in eWOM communication in social networks. Secondly, this comprehensive study provided an extended theoretical perspective on eWOM literature in the contaxt of an emerging market and clearly investigated the motivating factors of eWOM communication. A better understanding of these factors is critical for the effective use of eWOM as a viral and sustainable marketing strategy in this market and potentially other emerging markets.

This study also provided important managerial insights into business practices. Social media is used extensively to promote viral marketing because of its connecting power and online interpersonal relationships. The results of this study showed that reciprocity, tie strength, trust, and interaction service quality are the key factors that encourage users to share their experiences with others on social media platforms. In order to use SNSs as a marketing channel and eWOM as an important marketing strategy in a sustainable way, some valuable guidelines for SNS practitioners and marketing managers are presented below.

Reciprocity: Individuals are likely to enter into an exchange relationship with other online users if they find it beneficial. Therefore, social media managers or practitioners should create an atmosphere where members can easily share their opinions, browse others posts, provide feedback, and share links, which in turn can be beneficial to them.

Tie strength: To encourage more users to share their opinions, SNS media operators need to consider the influence of eWOM's structural features when interacting with potential and existing users on social media. SNS media operators can organize events to increase interaction among users.

Trust: The relational dimension trust inspires members to act and to achieve objectives of the group by helping each other. In order to build trust, SNS managers should pay attention to vibrant changes in trust mechanisms in terms of social influence, privacy concerns, and other attributes.

Interaction service quality: Social media platforms should provide self-guided solutions on their websites for problems that SNSs users are usually confronted with. Customer service employees must demonstrate their willingness to solve customer problems thoroughly.

While this paper provided a number of significant insights into eWOM communication for practitioners and managers, there were still some limitations that need to be explored further. Firstly, this study only considered key motivators from three different sources of psychological literature. There are probably other determinants that influence the eWOM communication of SNS users. Secondly, this study only considered positive eWOM, while negative eWOM may also be important; thus, future studies should continue to examine the factors that stimulate negative eWOM. Thirdly, the sample size was relatively small, and more than $50 \%$ of respondents were young, which might limit the generalizability of the study.

Therefore, although the explanatory power of the research model was sufficiently high, it is nevertheless suggested that future trials should examine the theoretical research model provided in this study, including other related constructs (e.g., subjective norms, risk factors, etc.). In order to achieve a clearer understanding of eWOM in SNS, future research may measure negative eWOM using the proposed model. Future trials may investigate eWOM communication in a more diversified manner, with a larger sample in a more realistic way, thus expanding knowledge on this paradigm.

Author Contributions: M.A.H. generated the research idea, wrote the manuscript, and designed the survey. The other authors suggested research ideas and contributed to the revision of the manuscript. All authors read and approved the final manuscript.

Acknowledgments: The authors would like to thank the editors and the anonymous reviewers who provided valuable and constructive comments on this manuscript. 
Conflicts of Interest: The authors declare that there are no conflicts of interest. This research received no funding from any source.

\section{References}

1. Chen, Y.; Xie, J. Online consumer review: Word-of-Mouth as a new element of marketing communication mix. Manag. Sci. 2008, 54, 477-491. [CrossRef]

2. Ma, L. Electroninc Word-of-Mouth on Microblogs: A Cross-cultural Content Analysis of Twitter and Weibo. Intercult. Commun. Stud. 2013, 3, 18-42.

3. Wang, T.; Yey, R.K.J.; Chen, C.; Tsydepov, Z. What drives electronic word-of-mouth on social networking sites? Perspective of social capital and self-determination. Telemat. Inform. 2016, 33, 1034-1047. [CrossRef]

4. Harvard Business Review. 2011. Available online: https://hbr.org/2011/06/why-customer-referrals-candrive-stunning-profits?referral=03759\&cm_vc=rr_item_page.bottom/ (accessed on 14 January 2018).

5. Trusov, M.; Bucklin, R.E.; Pauwels, K. Estimating the dynamic effects of online word-of-mouth on member growth of a social network site. J. Market. 2009, 73, 90-102. [CrossRef]

6. Xie, C.; Putrevu, J.S.H.; Linder, C. Family, Friends, and Culture Connectedness: A Comparison Between WeChat and Facebook User Motivation, Experience and NPS among Chinese People Living Overseas. In International Conference on Cross-Cultural Design; Springer International Publishing: Cham, Switzerland, 2017; pp. 369-382.

7. Phua, J.; Jin, S.V.; Kim, J. Uses and gratifications of social networking sites for bridging and bonding social capital: A comparison of Facebook, Twitter, Instagram, and Snapchat. Comput. Hum. Behav. 2017, 72, 115-122. [CrossRef]

8. Zephoria. The Top 20 Valuable Facebook Statistics Updated January 2018. 2018. Available online: https: / zephoria.com/top-15-valuable-facebook-statistics / (accessed on 7 February 2018).

9. Baker, P.M.; Bricout, J.C.; Moon, N.W.; Coughlan, B.; Pater, J. Communities of participation: A comparison of disability and aging identified groups on Facebook and LinkedIn. Telemat. Inform. 2013, 30, 22-34. [CrossRef]

10. Cheung, C.M.; Lee, M.K. What drives consumers to spread electronic word of mouth in online consumer-opinion platforms. Decis. Support Syst. 2012, 53, 218-225. [CrossRef]

11. Kucukemiroglu, S.; Kara, A. Online word-of-mouth communication on social networking sites: An empirical study of Facebook users. Int. J. Commer. Manag. 2015, 25, 2-20. [CrossRef]

12. The Asian Age. Social Media Trends Usages in Bangladesh. 2017. Available online: https://dailyasianage. com/news/46958/social-media-trends-usages-in-bangladesh/ (accessed on 14 January 2018).

13. Xia, L.; Bechwati, N.N. Word of mouse: The role of cognitive personalization in online consumer review. J. Interact. Adv. 2008, 9, 108-112. [CrossRef]

14. Chu, S.C.; Kim, Y. Determinants of consumer engagement in electronic word-of mouth (eWOM) in social networking sites. Int. J. Adv. 2011, 30, 47-75. [CrossRef]

15. Chung, N.; Tyan, I.; Chung, H.C. Social Support and Commitment within Social Networking Site in Tourism Experience. Sustainability 2017, 9, 2102. [CrossRef]

16. Lien, C.H.; Cao, Y.; Zhou, X. Service quality, satisfaction, stickiness and usage intentions: An exploratory evaluation in the context of WeChat services. Comput. Hum. Behav. 2017, 68, 403-410. [CrossRef]

17. Hossain, M.A.; Kim, M. Does Multidimensional Service Quality Generate Sustainable Use Intention for Facebook? Sustainability 2018, 10, 2283. [CrossRef]

18. Lakhani, K.R.; Hippel, E.V. How open source software works: 'Free' user-to-user assistance. Res. Policy 2003, 32, 923-943. [CrossRef]

19. Wasko, M.M.; Faraj, S. Why should I share? Examining social capital and knowledge contribution in electronic networks of practice? MIS Q. 2005, 29, 35-57. [CrossRef]

20. Shiau, W.L.; Luo, M.M. Factors affecting online group buying intention and satisfaction: A social exchange theory perspective. Comput. Hum. Behav. 2012, 28, 2431-2444. [CrossRef]

21. Bourdieu, P. Handbook of Theory and Research for the Sociology of Education; Greenwood: New York, NY, USA, 1986; pp. 241-258.

22. Lee, D.; Kim, H.S.; Kim, J.K. The role of self-construal in consumers' electronic world of mouth (eWOM) in social networking sites: A social cognitive approach. Comput. Hum. Behav. 2012, 28, 1054-1062. [CrossRef] 
23. Zhao, L.; Lu, Y.; Zhang, L.; Chau, P.Y. Assessing the effects of service quality and justice on customer satisfaction and the continuance intention of mobile value-added services: An empirical test of a multidimensional model. Decis. Support Syst. 2012, 52, 645-656. [CrossRef]

24. Gounaris, S.; Dimitriadis, S.; Stathakapolos, V. An examination of the effects of service quality and satisfaction on consumers' behavioral intentions in e-shoping. J. Serv. Market. 2010, 24, 142-156. [CrossRef]

25. Srinivasan, S.S.; Anderson, R.; Ponnavolu, K. Customer loyalty in e-commerce: An explanation of its antecedents and consequences. J. Retail. 2002, 78, 41-50. [CrossRef]

26. Chaniotakis, I.E.; Lymperopoulos, C. Service quality effect on satisfaction and word of mouth in the health care industry. Manag. Serv. Qual. 2009, 19, 229-242. [CrossRef]

27. Anderson, J.C.; Gerbing, D.W. Structural equation modeling in practice: A review and recommended two-step approach. Psychol. Bull. 1988, 103, 411-423. [CrossRef]

28. Hair, J.F.; Black, W.C.; Babin, H.J.; Anderson, R.E. Multivariate Data Analysis, 7th ed.; Pearson Education Inc.: Upper Saddle River, NJ, USA, 2010.

29. Fornell, C.; Larcker, D.F. Evaluating structural equation models with unobservable variables and measurement error. J. Market. Res. 1981, 18, 39-50. [CrossRef]

30. Podsakoff, P.M.; MacKenzie, S.B.; Lee, J.Y.; Podsakoff, N.P. Common method biases in behavioral research: A critical review of the literature and recommended remedies. J. Appl. Psychol. 2003, 88, 879-903. [CrossRef] [PubMed]

(C) 2019 by the authors. Licensee MDPI, Basel, Switzerland. This article is an open access article distributed under the terms and conditions of the Creative Commons Attribution (CC BY) license (http:/ / creativecommons.org/licenses/by/4.0/). 